11. Mints A. A. Ekonomicheskaya otsenka estestvennykh resursov (nauchno-metodicheskie problemy ucheta geograficheskikh razlichiy i effektivnosti ispol'zovaniya). Moscow: Mysl', 1972. 303 p.

12. Palamarchuk M. M., Palamarchuk O. M. Ekonomichna i sotsialna heohrafiia Ukrainy $\mathrm{z}$ osnovamy teorii: textbook. Kyiv: Znannia, 1998. $416 \mathrm{p}$

13. Popovkin V. A. Povyshenie roli kompleksnykh territorial'nykh planov v ekonomicheskom i sotsial'nom razvitii. Kyiv: Znannya, 1986. $123 \mathrm{p}$

14. Dong C., Schoups G., van de Giesen N. Scenario development for water resource planning and management: A review // Technological Forecasting and Social Change. 2013. Vol. 80, No. 4. P. 749-761. doi:10.1016/j.techfore.2012.09.015

15. Dorohuntsov S. I., Mukhovykov A. M., Khvesyk M. A. Optymizatsiia pryrodokorystuvannia. Vol. 1. Pryrodni resursy: ekoloho-ekonomichna otsinka. Kyiv: Kondor, 2004. 291 p.

16. Dzhyhyrei V. S. Ekolohiia ta okhorona navkolyshnoho pryrodnoho seredovyshcha. Kyiv: Znannia, 2007. 422 p.

17. Granberg A. G. Osnovy regional'noy ekonomiki. Moscow: Izdatel'skiy dom GU VSHE, 2004. 495 p.

18. Chung G., Lansey K., Bayraksan G. Reliable water supply system design under uncertainty // Environmental Modelling \& Software. 2009. Vol. 24, No. 4. P. 449-462. doi:10.1016/ j.envsoft.2008.08.007

19. Priority water research questions as determined by UK practitioners and policy makers / Brown L. E. et al. // Science of The Total Environment. 2010. Vol. 409, No. 2. P. 256-266. doi:10.1016/j.scitotenv.2010.09.040

20. Bun E. K., Khens L. Ot deklaratsii tysyacheletiya - k Yokhannesburgskoy deklaratsii: uroki i perspektivy ustoychivogo razvitiya // Metody resheniya ekologicheskikh problem / ed. by Mel'nik L. G., Sabadash V. V. Sumy: Kozatskiy val, 2005. P. 211-224.

21. Rekish A. A. Ekonomicheskie, ekologicheskie, sotsial'nye osnovy razrabotki otsenok napravleniya razvitiya ekonomikoekologicheskikh sistem. Odessa: ODEKU, 2010. 125 p.

22. Serbov N. G. Ekonomicheskie osnovy ekologizatsii proizvodstvenno-khozyaystvennoy deyatel'nosti v vodnykh basseynakh
Ukrainy // Vestnik Dnepropetrovskogo universiteta. Seriya: Ekonomika. 2011. Vol. 19, No 10/1. P. 63-68.

23. Evaluating participation in WFD river basin management in England and Wales: Processes, communities, outputs and outcomes / Benson D. et al. // Land Use Policy. 2014. Vol. 38 P. 213-222. doi:10.1016/j.landusepol.2013.11.004

24. Naukovi zasady ratsionalnoho vykorystannia vodnykh resursiy Ukrainy za baseinovym pryntsypom / Stashuk V. A. et al.; ed. by Stashuk V. A. Kherson: Vydavnytstvo Hryn, 2014. 320 p.

25. Optimal sequencing of water supply options at the regional scale incorporating alternative water supply sources and multiple objectives / Beh E. H. Y. et al. // Environmental Modelling \& Software. 2014. Vol. 53. P. 137-153. doi:10.1016/ j.envsoft.2013.11.004

МЕТОДОЛОГИЧЕСКИЕ ПОДХОДЫ В РАЗРАБОТКЕ СТОИМОСТНОЙ ОЦЕНКИ ЗАТРАТ ПРЕСКОВОДНЫХ РЕСУРСОВ ВОДНОГО БАССЕЙНА ОБЪЕКТАМИ ПРИРОДОЛОЛЬЗОВАНИЯ

Рассмотрены методические подходы к оценке затрат на подготовку и использование пресноводных ресурсов водного бассейна при различных видах хозяйственной деятельности. Рассмотрена оптимальная стратегия безопасного и сбалансированного развития экономико-экологической системы водного бассейна. Предложена схема стоимостной оценки затрат на непроизводственные потери природного ресурса при его первичной и специальной подготовке.

Ключевые слова: пресноводные ресурсы, оценка потерь, затраты на подготовку природного ресурса.

Serbov Mykola, PhD, Associate Professor, Vice-Rector for Academic Affairs, Odessa State Environmental University, Ukraine e-mail:serbov@odeku.edu.ua,ORCID:http://orcid.org/0000-00020220-6745

\section{Kharenko D., Dyshkantiuk 0., Ivychuk L.}

\title{
ANALYSIS OF GASTRONOMIC EVENTS: A CASE STUDY OF PORTUGAL
}

Проведено дослідження традичійних гастрономічних фестивалів в Португалії. Визначено, наскільки іх конщепція задовольняє сучасні потреби відвідувачів в здобутті унікального досвіду. Результати дослідження підтверджують, що гастрономічні фестивалі мають великі соціальноекономічні перспективи для розвитку. Був проведений збір і обробка статистичних даних $і$ внаслідок аналізу дані рекомендащії щодо поліпшення маркетингової стратегї і дизайну подій.

Ключові слова: гастрономічні фестивалі, дизайн подї, організащія заходів, подієвий туризм, досвід відвідувачів, економіка вражень.

\section{Introduction}

The interrelation between gastronomy and tourism is currently undeniable, not only because it is an integral part of the tourist experience, but also because it is a trend [1]. In some cultures, cooking is seen as an art, and good cooks become celebrities. Each nation and nationality on Earth has unique culinary traditions. Obviously, it is possible to learn a lot about a country by its kitchen. Gastronomic tourism is gaining popularity among tourists looking for unique emotions, gaining a distinctive experience, taking part in local gastronomic events.
A modern trend in gastronomic tourism is that the consumer is more inclined to take an active position in getting sensory and emotional experience, rather than just being a passive consumer.

Gastronomic festivals, like events aimed at providing the visitor with bright sensory impressions - call for greater involvement of visitors in the process of producing gastronomic products. Thus, they receive a unique sensory experience, are attached to local cultures and interact with local residents. Active involvement of tourists in local traditions is a modern tourist trend. Thus, the quality of the tourist service provided is closely 
interrelated with the experience and experiences experienced.

The role of gastronomic experience in tourism is a relatively recent area of research. Research, as a rule, focuses on food as a key element of tourism experience, the classification of gastronomic tourists, marketing strategy of promotion and positioning of local food are defined.

However, insufficient research has been done on the nature of the experience of gastronomic festivals received by visitors [2]. Little research has been done on the impact of gastronomy on local events. Trends in food consumption by visitors to cultural events are insufficiently studied.

In addition, scientific works on gastronomy as a tourist product are still being created [3]. This is probably due to the fact that food and gastronomy were perceived earlier as a secondary tourism product, but the situation has changed and now it is gastronomy, more and more often, that plays a key role.

Taking into account the importance of events in general and gastronomic festivals in particular as a basis for the development of tourism experience, this research is relevant and aimed at obtaining data on gastronomic festivals and the experience gained on them.

\section{The object of research and its technological audit}

The object of research is the traditional gastronomic festival's design in the region of Minho (Northern Portugal), namely, how its concepts and organization ensure the need for visitors to receive authentic, holistic experience. As typical examples for the study of traditional gastronomic festivals, such events as Festa de São Silvestre (Viana do Castelo), Festa dos Reis (Valença), IX Feira do Porco e as Delícias do Sarrabulho (Ponte de Lima), which took place in the winter 2016-2017.

The Portuguese are very fond of conducting numerous festivals and having fun - it has become their national identity. There are many festivals that take place during the calendar year. Many of them are associated with various dishes or food products, for example sardines, snails, chocolate. Some of the Portuguese festivals derive from the traditional customs of the local population. The program also features musical entertainment and animation. The originality and massiveness of such events is one of the main cultural attractions of the country.

Portuguese cuisine, as well as culture is rich and diverse. River and sea fish dishes are typical in this region. Some of the local delicacies are considered typical Portuguese dishes, for example Bacalhau (fish dish) and sarrabulho (meat dish). There are many other local dishes that are also widely known outside the region and are a source of pride for the local people.

The International Institute of Gastronomy, Culture, Arts and Tourism (IGCAT), under its project 'European Region of Gastronomy' (ERG), was awarded Minho and Catalunya with the title of the European Region of Gastronomy of 2016 [4]. This fact served as one of the incentives for conducting a study of consumer behavior of visitors to gastronomic festivals.

Traditional gastronomic festivals are very interesting and unique, they certainly have very great potential for growth. But at the moment the results show that the ability to attract visitors from different regions and countries is negligible, since the majority of visitors are local residents. One of the reasons that the Minho region has not received international fame is that gastronomic tourists do not know enough about the local cuisine and rarely visit Minho and Portugal. Festivals should develop and implement a new concept of development, which will attract more and more tourists, especially from other countries. To ensure the competitiveness of gastronomic festivals and tourist destinations, it is necessary to identify and satisfy the needs of visitors, given their motivation and desires. This is what will ensure loyalty and attract tourists. As an example of the object of research, a typical, traditional, local gastronomic festival in the region of Minho in northern Portugal is chosen.

\section{The aim and objectives of research}

The aim of research is analysis of the organization, results and prospects for the development of gastronomic festivals. This analysis is done in order to determine whether the festivals provide a unique tourist experience and whether they are competitive.

To achieve this aim, the following tasks are defined:

1. To conduct a study of the profile, the main motivations, the characteristics of the visit, the perception of the festival and the quality of the experience gained by visitors to the gastronomic festival.

2. To give recommendations on the improvement and development of the festival, based on the data obtained from analysis and tourist trends.

\section{Research of existing solutions of the problem}

Global competition between tourist destinations is growing in the market. This means that tourism should develop in accordance with the characteristics of the market and the resources of the region, creating a balance between the tourist offer and the needs of visitors. Destination should provide an opportunity to gain new experience for visitors, thanks to its participation in the event and interaction with the environment. All this as a whole should ultimately lead to the «WOW» effect. This will ensure the satisfaction of visitors, which, in turn, should improve the popularity of the tourist destination [5]

According to authoritative experts, humanity has entered a new economic era, Experience Economy (or the economy of consumer experience), when the main battlefield for the customer is the management of consumer experience [6]. Modern economies are evolving towards providing services that are oriented toward gaining experience [7]. Consumer experience, according to different sources, «is the total experience gained by the consumer when interacting with the company/brand throughout the life cycle of their relationship» [8]. Tourist experience is a very subjective and individual concept, arising from the reaction of each person to a number of physical, social, sensory stimuli, including food products, which affect everyone individually [9].

Tourist products must meet the various needs of the tourist and provide appropriate benefits and experience [10]. Unlike goods, services that provide experience are remembered and, consequently, can have an indelible impression on visitors while at the same time increasing their satisfaction. 
Consequently, in today's increasingly more sophisticated consumer environment, those who travel products that provide unforgettable customer experiences are valued and bring competitive advantages [11].

At many tourist events, food and drinks are closely related to the main theme and program, but almost at all gastronomic events gastronomy is of paramount importance. This is true at the festivals of food and wine, gala dinners and other events that emphasize cultural authenticity. «Food and meals are a central field in the communication of culture» [12].

Historically, elements such as food and drinks served as a supporting role in the tourism economy, as they were not generally considered to be the main attraction for tourists to a tourist destination. Gastronomic experiences are often taken for granted, because food is seen as a necessity, not leisure. However, the trend is changing and many enterprises are considering the importance of gastronomic experience. In the tourism industry facing the consequences of the global crisis, tourist regions often use gastronomy as a driving force to revitalize their cultural and tourism potential. For these destinations, gastronomy is the main tourist attraction and the main attraction element [13].

Gastronomy is an attractive element around which it is possible to create a unique experience, encouraging tourism destinations to include local food and drinks in a tourist product. In addition, gastronomy is not only identified with food, but often includes food preferences, wine, heritage, traditions and landscapes. This is especially important in today's context, in the context of globalization and when tourist destinations compete with each other. Travel companies expand their offerings in such way as to satisfy the needs of modern visitors, paying special attention to the identity and uniqueness of local food and gastronomy [14].

Cultural events can be considered good examples of tourist experience, and can have a big impact on the competitiveness of the tourist destination. They have the opportunity to attract visitors and investments - as they are an important tourist motivator for the growth of the economy of the region as a whole. In addition, events are often used as marketing events [15]. Events are an environment for gaining experience, and therefore activities need to be designed to facilitate maximum satisfaction of their visitors' needs [5].

The festival's design is an extremely important aspect. Graphic design, apparently, can be considered as one of the important elements of the festival. In fact, design is a distinctive feature, being a competitive advantage.

Cultural events, such as gastronomic festivals, can be an excellent background for enrichment and cultural experience [16]. These events are mainly focused on getting emotions. Thus, the literature shows that gastronomic events and other cultural events have all the prerequisites for attracting consumers to the tourist region [7].

The result of gastronomic events is connected with the personal perception of the event by the visitor, the level of participation and the degree of interaction with the visited place. Therefore, event designers should consider these elements [11].

\section{Methods of research}

There is a wide variety of methods for studying tourist experience [11]. In this study, it is decided to conduct a survey based on a quantitative approach, by completing the questionnaire. This technique is often used to study gastronomy and tourism, according to the relevant literature.

To conduct these studies, a survey-based approach is chosen [17]. This strategy is often used to study the social sciences and hospitality and tourism in particular. This involves collecting information from a sample of respondents who respond to a number of predefined issues that are considered promising for research. Thus, a quantitative study is conducted using a questionnaire.

5.1. Research design. In this study, a typical data collection methodology is used to identify the main social, cultural and economic characteristics of various festivals around the world. For example, this methodology is used by the Association for Tourism and Leisure Education and Research (ATLAS) and allows comparisons between different studies. Some questions have been adapted to better fit specific research objectives, namely the perception of visitors with respect to various aspects of the experience. For the analysis of these elements, the seven-point Likerttype scale is used to evaluate some of the responses, to obtain information about the event, the results of participation, general feedback and the perception of the festival.

The questionnaire consists of twenty-six questions. The questionnaires are compiled in English, Portuguese, Spanish and French.

The questionnaire is devoted to assessing the effectiveness and quality of the drinks. The goal is covering most aspects of the concept of the festival in order to understand if it fits current market trends. It is important to offer visitors a holistic experience that arises from the interaction of sensual (sensory), emotional (sensory), cognitive (mental), behavioral (acts) and social (interrelated) experiences [11]. Thus, a set of statements reflecting the holistic experience is introduced. The questions revealed the authenticity of the experience, since the provision of such experience can be considered as part of the product of the event and can increase the satisfaction of tourists [7]. Taking into account that only when the client participates in a unique and memorable moment, then this experience takes place to be and is remembered [18]. Such characteristics as the diversity of the program, the activities in which the visitor can engage in, the uniqueness and distinctiveness of the festival have been included in the questionnaire.

The questionnaire focuses on the behavior of visitors, their main reasons for visiting, the overall level of satisfaction, the likelihood of a repetition of the visit and the desire to recommend the event to others.

One of the sections is designed to obtain demographic data in order to better define the visitor's profile: residence, gender, age, education, profession, income level, family.

The last section of the tool is given to questions of gastronomy. Questions such as: the awareness of festival visitors that the Minho region, where the gastronomic festival is held - in 2016 nominated as the European Region of Gastronomy, were visited by visitors to other gastronomic festivals and their relation to them, what festivals they would like to visit in the future, whether they tried local food and drinks and whether they bought for the house what foods of the gastronomy liked and which did not.

5.2. Data collection. The survey was conducted among visitors to gastronomic festivals in Minho in the winter 
of 2016. For this study, the sampling method was chosen. The survey was conducted by a group of 10 interviewers (including one of the authors of this article Dmytro Kharenko). The whole process was carried out individually with each of the visitors. If the visitor could spend a few minutes, the researcher could say the following phrases: «Tell us what you think of this event. We are investigating the social, cultural and economic impact of events and this survey will provide important information about how people experience different events». After filling out the questionnaire, the visitor was thanked for the cooperation and if he (or she) was not opposed to assisting in scientific research in the future, he provided contact information (e-mail).

A total of 232 questionnaires were filled in such events at events such as Festa de São Silvestre, Festa dos Reis, Valença the IX Feira do Porco e Delicias do Sarrabulho (Ponte de Lima) and others.

\section{Research results}

The IBM SPSS (Statistical Package for the Social Sciences) software was used to process the statistical data. To achieve the proposed research objectives, a variety of data analysis procedures were used. Although the analysis in this article mainly focuses on descriptive statistics, an analysis of the existing differences between groups of visitors was carried out (for example, between groups of visitors based on their previous experience (never visited, visited once, visited multiple times.) Nonparametric tests were used that allows to make comparisons between groups of respondents It was necessary to understand whether there are significant differences in the perception of experience among a group of visitors. Kruskal-Wallis and Spearman Rank correlation were used.

All data received in the SPSS program was processed and provided in the form of visual tables and graphs. Within the format of this article, it is impossible to display all the results of the study and provide them in the form of tables and graphs, but it is possible to describe the main results.

6.1. Visitor profile. The distribution of respondents by gender is almost the same. Age is mainly from 30 to 39 years. Visitors are generally quite educated (with a high percentage of having a higher education) and mostly with employees (service) or technical professions. It seems that the festival attracts mostly Portuguese guests mainly from the area of Minho or regions within a radius of $100 \mathrm{~km}-75.34 \%$. This shows that these festivals are local events, and those foreigners who participated in the survey were mostly Portuguese, who came to their relatives or friends to visit (based on personal communication data).

6.2. Reasons for attending the event. The main motivation for participation in the event is the opportunity «to spend time with family and friends» or «simply because people like the festival». Very few respondents expected to «try something new» or «learn something».

6.3. Festival as a motivation to visit the region. An important aim of research is understanding whether the festival is a motivator for attending a destination? It is the visit to destination by non-residents that promotes the development of tourism in the region. The festival is important for attracting visitors to their destination. $24.3 \%$ of respondents said that the festival was the main motivation for a visit. Only $19.5 \%$ believe that the festival is not a determining factor and in any case would visit the destination. This corresponds to a high percentage of visitors who stated that they would stay at home or leave for work if the event was not held (36.9\%).

6.4. Characteristics of the visit. Most visitors usually visit the festival in pairs, and $87.6 \%$ of groups, including children, make a difference that for more than half of the respondents, $87.6 \%$ is the first time they attend the festival. Considering that the festival is a traditional local event - therefore it is normal that $82.4 \%$ of respondents stay at home, and only $8.5 \%$ of respondents stay at the hotel. $9.1 \%$ of people live with friends or relatives.

The results also show that most visitors first learned about the festival through friends or family (45.9\%), emphasizing the importance of the word «word of mouth» in the form of the festival's transfer. On the contrary, other means of communication were least often mentioned, such as websites (like the event website, and others), tourist information offices and brochures. This indicates a clear lack of marketing efforts aimed at promoting the festival itself, and the festival within the destination in particular.

6.5. Visitors Expenditures. As for the expenses of visitors, they spend on average about 30 euros at the festival. It is important to note that most visitors not only use local food and drinks, but buy home as souvenirs or gifts for friends or relatives. In the literature it is shown that gastronomic products are memorable souvenirs that tourists take away in order to share a part of their experience with other people.

6.6. Gastronomic experience. One of the aims of the study is finding out if the visitors knew about Minho as the European gastronomy region of 2016. Only about $30.1 \%$ of respondents knew about the classification. Since the majority of respondents are local $(75.34 \%)$ - this may indicate that marketing and communication approaches to advancing the destination are ineffective. One of the other goals is identification of customer patterns of gastronomic events. Almost all visitors tried local traditional dishes at the event, as well as bought local products $(39.5 \%)$ and local wine Vinho Verde (24.7 \%) to take home. The study also confirms that, as a favorite gastronomic product, the visitors are named Sarrabulho (40\%) Rojões (13.8\%), and other local dishes. The same rating is compiled in the case of dishes that do not like. It is established that the prices for local dishes correspond to their quality and visitors actively buy them for themselves and as gifts. The local gastronomy of Minho is still one of the main reasons for participating in the events, but it has also been shown that the availability of local products for servants for home reception is both a necessity and an opportunity for earning for the organizers of the event.

6.7. Festival experience. The results show that visitors appreciate the indicators concerning the material aspects of the event, such as the quality of traditional gastronomy, and not the uniqueness of the experience gained during the event.

Basically, the participation of feelings and emotions manifest itself because of the sensory attractiveness of gastronomy. However, it turned out that the cultural program of the festival is considered its weakest point in terms of the number and variety of activities and it could not attract visitors to more active behavior. Unique and distinctive elements of the event also received a low rating. 
Therefore, the festival needs to improve its entire organization for future development in order to meet the needs of a new and demanding tourist who strives to improve his creative experience. As shown by the comparative analysis - between groups of visitors, there is a clear trend. For example, visitors for whom the festival is not motivated to visit the city, assess the quality of the festival and the gained holistic experience by lower ratings.

Nevertheless, in general, visitors consider their overall experience to be positive and plan to repeat their visit in the future.

\section{SWOT analysis of research results}

Strengths. Strengths of the research object include that: - local people appreciate the gastronomic traditions of the region, participate in them in every possible way and like to visit local gastronomic festivals;

- the festival is perceived by visitors as a good opportunity to spend pleasant time with family and friends; - the festival has a local status and the logistics and the organization of the event are simplified;

- good price/quality ratio;

- quality food and a wealth of traditional cuisine.

Weaknesses. The weak points of the research object are that:

- the program of gastronomic festivals requires improvement in order to be interesting, diverse and stimulate activity;

- insufficient interaction between stakeholders;

- ineffective marketing to promote local gastronomic events in other regions and abroad;

- geographical distance from tourist flows.

Opportunities. Festivals can use their potential not only as a local event, but be popular abroad if they make the most of their potential as a tourist destination.

Threats. Competition from other destinations that use innovative approaches for their promotion or provide other advantages (low price, investment, favorable location, developed infrastructure, etc.).

\section{Conclusions}

1. After the research, the main data necessary for analysis are obtained:

- the main demographic and socio-economic characteristics of the visitor. Most of the visitors are local residents, 30-39 years old, working in the service sector with an average income;

- motivation and basic characteristics of the visit.

Mostly the visitors want just to have a good time in the company of friends and family;

- the quality of the gained experience. One of the main directions of the research is studying the opinion of the visitors of the gastronomic festivals in Minho about the authentic experience of participation in the festival both with respect to the quality of the event and with regard to personal satisfaction.

The results show that the festival is perceived by visitors as a good practice and provides them with a pleasant experience and impressions. Therefore it is not surprising that the desire to re-visit the festival $(75 \%)$ and recommend visiting his friends ( $88 \%$ ) is also high. In fact, the analysis reveals a direct relationship between the intention of visitors to visit the festival in the future (loyalty) and the level of satisfaction. This result coincides with the regularity that a motivated gastronomic tourist is a loyal market, as evidenced by a review of the literature.

Despite the overall positive feedback received from visitors who claim that the concept of the festival is still attractive, the results indicate that some adjustments are needed. This primarily applies to the design of the festival, as a means to obtain tourist experience.

In preparation for the festival next year, the organizers should revise the approach, taking into account the current and emerging trends in the tourism market. The festival can still make the most of its potential as a local event and provide the expected economic and socio-cultural benefits for both the region and visitors. To this end, organizers and managers must increase competitiveness and improve the quality of the festival in the future.

2. The following recommendations are made:

1) Program and development of experiences. Festivals should provide a more holistic unique experience that can distinguish them from competitors and attract more visitors each year. Organizers must adapt the festival program to various characteristics and varieties of experience such as: unique, memorable, exciting and emotional experience.

The program needs to be improved, being one of the weakest aspects of the festival. For this, it is necessary to develop various entertainment events within the framework of the festival program. The program should be diverse and attractive for different visitors, with different motivations and level of knowledge. For example: sensory tastings, or cooking contests among participants. The complex interaction of design elements with the theme and program, the quality of service and the provision of products is directly related to experience.

The topic of the event should be a powerful interpretation tool for achieving memorizing and transforming events and achieving the desired «WOW!» effect. A quality program can be used by designers to create unique events, including specific activities for guests (for example, games, assignments, learning opportunities), sensory and emotional stimulation.

The experience of participation in the event is the key factor in the formation of the satisfaction level. Quality of service and management are also design processes, especially because quality service (staff and volunteers) can be part of the experience.

2) Improvement of the space of the festival. The festival space should be organized in such way as to promote interaction between visitors and allow them to participate in activities that require active participation. In addition, it would be appropriate to make a division by zones. Separately, it is possible to place a zone of children's animation, entertainment, music and shopping. But at the same time, do not allow isolation of zones and promote interaction between visitors. In addition, it is necessary to provide rapid orientation in space and time providing information support (pointers, maps, audio announcements).

3) Integration of the festival within the host region. One of the main strategic shortcomings of the festival is that it does not promote integration and interaction with the region. This integration is necessary to ensure the demand for other tourist facilities (hotels, restaurants, sightseeing firms). This is lead to the development of tourism in the region as a whole. Therefore, the festival should promote 
activities throughout the region and attract visitors. For example, cooking lessons and competitions can be developed, as well as various seminars.

Actions should be taken to promote a unique experience in the destination. For example: correctly position and advertise local gastronomy and wines, organize inserts, concerts, craft fairs, walking routes.

4) Monitoring of the performance of the festival, and actions undertaken. Today it is well known that monitoring should be considered as an integral part of any plan. Monitoring and evaluation of the effectiveness of the destination or product allows assessing its success in achieving strategic priorities, providing a basis for future solutions. In this sense, and in the end, it is necessary to ensure constant monitoring of the festival and evaluate the changes.

5) Food as and source of experience. As it was already noted, food and drinks at many events are not only a basic service, but also a source for gaining experience. Food and drink should be offered as a unique cultural experience, not just offered for sale as goods. It is necessary to consider the key elements of the food experience (eating experience): «the occasion; the company one dines with; atmosphere; food; service, and setting» [19].

The product consists of a visual effect, a taste/expectancy match, a style reflection and a standard of service. The entire production process requires skill, science, and knowledge of etiquette in order to present a good food product and provide a pleasant experience for the guest. All the senses must be involved and be in harmony, so that the experience of eating is positive [20].

6) Souvenirs and gifts. Gift products and souvenirs are also important at some events, including those in which sponsors provide samples to take them home. In these cases, material values are a key part of the experience of events, so their qualitative characteristics and how they are presented are critical. For marketers, each such gift is branding and sponsors want visitors to leave with a favorable and sustainable perception of the brand.

7) Reinforcement of Marketing efforts. Along with these actions it is important to promote the festival and the destination in the complex. Both the festival and the region do not make enough marketing efforts to attract visitors. This is illustrated by the high percentage of visitors who first heard about the festival from family and friends. Perhaps a good marketing strategy would be to promote the region and its products more creatively and attract different segments of the market. This will contribute to the formation of a distinctive image of the region.

8) Recommendations for future research. It is recommended to conduct further studies to confirm the results of various components of the festival's design. First of all, it would be interesting to study the festival in future editions, in order to promote the dynamics of the festival's design, taking into account the implemented recommendations. It would be possible to conduct interviews and other statistical approaches to the study of gastronomic events in order to provide a more comprehensive analysis.

These are just a few recommendations as design elements, which in the end should create a unique cultural experience and the loyalty of the visitor. When preparing for the festival in the future, the organizers should reconsider the approach taking into account current and emerging trends in the tourism market.

\section{Acknowledgements}

First, I would like to thank my supervisor and teacher Professor Carlos Fernandes, who kindly helped me to carry out this research. Without a doubt, all the credit belongs to him and the Tourism Course at the IPVC (the Polytechnic Institute of Viana do Castelo (Portugal)). I would like to thank my friends and Master Students of the Tourism Course at the IPVC, who kindly helped me with all data collection. I would then like to thank Hugo Sousa, who helped me very much too and presented reports about this scientific research with me, at the ATLAS Annual Conference 2017 (12-15 of September 2017, Viana do Castelo, Portugal. I also want to express my gratitude to the Erasmus Mundus for a great internship opportunity (from 15.09.2017 to 15.04.2018 at the IPVC). To end with, a huge thank you to my friends and colleagues in science for all their support and friendship. It would definitely not have been easy without you.

\section{References}

1. Mak A. H. N., Lumbers M., Eves A. Globalisation and food consumption in tourism // Annals of Tourism Research. 2012 Vol. 39, No. 1. P. 171-196. doi:10.1016/j.annals.2011.05.010

2. Morgan M. Making space for experiences // Journal of Retail \& Leisure Property. 2006. Vol. 5, No. 4. P. 305-313. doi:10.1057/palgrave.rlp.5100034

3. Factors influencing tourist food consumption / Mak A. H. N. et al. // International Journal of Hospitality Management. 2012. Vol. 31, No. 3. P. 928-936. doi:10.1016/j.ijhm.2011.10.012

4. International Institute of Gastronomy, Culture, Arts and Tourism. URL: http://europeanregionofgastronomy.org/

5. Getz D. Event studies: theory, research and policy for planned events. Routledge, 2007. 476 p.

6. Pine B. J., Gilmore J. H. Welcome to the experience economy // Harvard business review. 1998. Vol. 76, No. 4. P. 97-105.

7. Robinson R. N. S., Clifford C. Authenticity and festival foodservice experiences // Annals of Tourism Research. 2012. Vol. 39, No. 2. P. 571-600, doi:10.1016/j.annals.2011.06.007

8. Dyshkantiuk O. V. Economy of impressions - current stage of Development of social production // Ekonomika kharchovoi promyslovosti. 2016. Vol. 8, No. 4. P. 3-9.

9. Ryan C. Tourist experiences, phenomenographic analysis, postpostivism and neural network software // International Journal of Tourism Research. 2000. Vol. 2, No. 2. P. 119-131. doi:10.1002/ (sici)1522-1970(200003/04)2:2<119::aid-jtr193>3.0.co;2-g

10. $\mathrm{Xu} \mathrm{J}$. B. Perceptions of tourism products // Tourism Management. 2010. Vol. 31, No. 5. P. 607-610. doi:10.1016/j.tourman.2009.06.011

11. Mason M. C., Paggiaro A. Investigating the role of festivalscape in culinary tourism: The case of food and wine events // Tourism Management. 2012. Vol. 33, No. 6. P. 1329-1336. doi:10.1016/j.tourman.2011.12.016

12. Tellstrom R., Gustafsson I.-B., Mossberg L. Consuming heritage: The use of local food culture in branding // Place Branding. 2006. Vol. 2, No. 2. P. 130-143. doi:10.1057/palgrave.pb.5990051

13. Kivela, J., Crotts, J. C. Gastronomy Tourism // Journal of Culinary Science \& Technology. 2005. Vol. 4, No. 2-3. P. 39-55. doi:10.1300/j385v04n02_03

14. Chang R. C. Y., Kivela J., Mak A. H. N. Attributes that influence the evaluation of travel dining experience: When East meets West // Tourism Management. 2011. Vol. 32, No. 2. P. 307-316. doi:10.1016/j.tourman.2010.02.009

15. Whelan S., Wohlfeil M. Communicating brands through engagement with «lived» experiences // Journal of Brand Management. 2006. Vol. 13, No. 4-5. P. 313-329. doi:10.1057/ palgrave.bm.2540274

16. Salamatina S. Stan ta perspektyvy rozvytku hastronomichnoho turyzmu na pivdni odeshchyny // Scientific Works ONAFT. 2014. Vol. 46, No. 2. P. 325-329.

17. Altinay L., Paraskevas A. Planning research in hospitality and tourism. Routledge, 2008. 262 p. 
18. Morgan M. Festival spaces and the visitor experience // Social and cultural change: Making space(s) for leisure and tourism. 2007. P. 113-130.

19. Lashley C., Morrison A., Randall S. More than a service encounter? Insights into the emotions of hospitality through special meal occasions // Journal of Hospitality and Tourism Management. 2005. Vol. 12, No. 1. P. 80-92.

20. The Five Aspects Meal Model: a tool for developing meal services in restaurants / Gustafsson I.-B. et al. // Journal of Foodservice. 2006. Vol. 17, No. 2. P. 84-93. doi:10.1111/ j.1745-4506.2006.00023.x

\section{АНАЛИЗ ГАСТРОНОМИЧЕСКИХ СОБЫТИЙ НА ЛРИМЕРЕ ПОРТУГАЛИИ}

Проведено исследование традиционных гастрономических фестивалей в Португалии. Определено, насколько их концепция удовлетворяет современным потребностям посетителей в обретении уникального опыта. Результаты исследования подтверждают, что гастрономические фестивали имеют большие социально-экономические перспективы для развития. Произведены сбор и обработка статистических данных. В результате их анализа даны рекомендации по улучшению маркетинговой стратегии и дизайна событий.

Ключевые слова: гастрономические фестивали, дизайн события, организация мероприятий, событийный туризм, опыт посетителей, экономика впечатлений.

Kharenko Dmytro, PhD, Senior Lecturer, Department of Hotel and Restaurant Business, Odessa National Academy of Food Technologies, Ukraine, e-mail: kharenko1980@gmail.com, ORCID: https:// orcid.org/0000-0001-7978-3287

Dyshkantiuk Oksana, PhD, Associate Professor, Department of Hotel and Restaurant Business, Odessa National Academy of Food Technologies, Ukraine, e-mail: dyshkantyuk.oksana@gmail.com, ORCID: https://orcid.org/0000-0001-9812-1916

Ioychuk Liliia, Assistant, Department of Hotel and Restaurant Business, Odessa National Academy of Food Technologies, Ukraine, e-mail: ivychuklilia@gmail.com, ORCID: https://orcid.org/0000-00021330-0702 